\title{
New Record Holders for Maximum Genome Size in Eudicots and Monocots
}

\author{
B. J. M. Zonneveld \\ National Herbarium of the Netherlands, Leiden University Branch, P.O. Box 9514, 2300 RA Leiden, The Netherlands
}

Correspondence should be addressed to B. J. M. Zonneveld, zonneveld@nhn.leidenuniv.nl

Received 27 January 2010; Accepted 15 March 2010

Academic Editor: Johann Greilhuber

Copyright ( 2010 B. J. M. Zonneveld. This is an open access article distributed under the Creative Commons Attribution License, which permits unrestricted use, distribution, and reproduction in any medium, provided the original work is properly cited.

This paper presents the largest genome sizes reported so far for angiosperms: for the monocots Trillium hagae (Melanthiaceae) $2 \mathrm{C}=264.9 \mathrm{pg}$ and for the eudicots Viscum album (Santalaceae) with $2 \mathrm{C}=205.8 \mathrm{pg}$. They were found during ongoing measurements of nuclear DNA content in more than 4000 accessions. Moreover, it is demonstrated that both of the values for the largest genome size so far for the monocots of Fritillaria assyriaca and for the eudicots of Viscum cruciatum need to be corrected.

\section{Introduction}

Until recently, genome size in angiosperms varied from $0.321 \mathrm{pg}$ in Arabidopisis thaliana (Brassicacae) [1] to $254.8 \mathrm{pg}$ in Fritillaria assyriaca (Liliaceae) [2], an 800-fold range. This genome size is not related to the number of genes (polyploids excluded) but is due to large amounts of repetitive DNA. Also the number of chromosomes is not very relevant as some plants with very high chromosome numbers have low amount of nuclear DNA like Sedum suaveolens with about $2 n=640$ and $18.3 \mathrm{pg}$ of DNA (Table 2). This is called the $\mathrm{C}$-value paradox or the C-value enigma [3]. Genome size is not very useful at higher taxonomic levels, but is especially of value at the species level [4-9]. The amount of nuclear DNA is positively correlated with nuclear and cellular volume, whereby mainly cell size is subjected to selection [10].

The smallest angiosperm genomes are found in the Lentibulariaceae with Genlisea margaretae with a 2C DNA value of only $0.129 \mathrm{pg}$ [11]. This is less than half the size of the genome of Arabidopsis thaliana with $2 \mathrm{C}=0.321 \mathrm{pg}$ [1] and seems to increase the total range from 800 to 1968 fold. At the other end of the scale always the monocot Fritillaria assyriaca with $2 \mathrm{C}=254.8 \mathrm{pg}$ is named as the species with the largest genome size for the angiosperms [2]. However, this is based on the wrong assumption [2], as will be demonstrated below, that Fritillaria assyriaca has the largest genome size. The supposed largest eudicot is Viscum cruciatum with $2 \mathrm{C}=158.6 \mathrm{pg}$. The present study presents the highest values reported so far. They were found during ongoing measurements of nuclear DNA content in more than 4000 accessions [4-9]. They represent a new record at the higher end of the scale of angiosperm C-values. This emphasizes the need for a proper explanation of these very large genome sizes.

\section{Material and Methods}

2.1. Plant Material. Trillium hagae material was obtained from the collection of C. Denton, UK. Viscum crassulae was obtained from E. van Jaarsveld of Kirstenbosch Botanical Garden RSA and Viscum minimum of C. Grootscholten Succulent Nursery, The Netherlands. Viscum album was obtained from the Botanical Garden Wageningen, The Netherlands, and also from Arboretrum Trompenburg Rotterdam, The Netherlands, and collected in south Limburg, The Netherlands; Pyrenees, France, and southern Greece. Live material of Fritillaria was contributed by P. Christian, J. de Groot, Hortus Bulborum Limmen, Potterton and Martin, W. Kletzing and M. de Jaeger. Where possible, material of known wild origin was used, and care was taken to ensure correct identification of all materials.

2.2. Flow Cytometric Measurement of Nuclear DNA Content. For the isolation of nuclei, about $1 \mathrm{~cm}^{2}$ of adult leaf tissue was chopped together with a piece of Haemantus albiflos (Amaryllidaceae) as an internal standard (see below). 
TABle 1: Genome sizes (2C) of Fritillaria species, standard deviation (SD), chromosome numbers, and number of accessions (\#), compared with McLeish and LaCour [1].

\begin{tabular}{|c|c|c|c|c|c|c|c|}
\hline Species & & $2 \mathrm{C}$ in $\mathrm{pg}$ & S.D. & $2 n^{*}$ & \# & McLeish and LaCour 2C in pg & Difference in pg \\
\hline Fritillaria & verticillata & 84.9 & 1.9 & 24 & 4 & 96.5 & 11.6 \\
\hline Fritillaria & pallidiflora & 87.4 & 1.3 & 24 & 2 & $* * * 116.7$ & 29.3 \\
\hline Fritillaria & raddeana & 91.1 & 0.7 & 24 & 2 & 119.5 & 28.4 \\
\hline Fritillaria & liliacea & 89.6 & 1.8 & 24 & 1 & 121.4 & 31.8 \\
\hline Fritillaria & pyrenaica & 104.9 & 3.1 & 24 & 3 & 127.4 & 22.5 \\
\hline Fritillaria & meleagris & 112.4 & 3.0 & 24 & 4 & 141.4 & 29.0 \\
\hline Fritillaria & imperialis & 102.5 & 1.3 & 24 & 5 & 145.0 & 42.5 \\
\hline Fritillaria & olivieri & 117.1 & 0.4 & 24 & 3 & 145.6 & 28.5 \\
\hline Fritillaria & acmopetala & 132.5 & 1.9 & 24 & 4 & 151.1 & 18.6 \\
\hline Fritillaria & glauca & 111.7 & 0.5 & 24 & 1 & 155.3 & 43.6 \\
\hline Fritillaria & crassifolia & 133.1 & 3.5 & 24 & 5 & 160.8 & 27.7 \\
\hline Fritillaria & tuntasia & 130.4 & 1.5 & 24 & 2 & 163.2 & 32.8 \\
\hline Fritillaria & pinardii & 131.1 & 1.6 & 24 & 4 & 164.4 & 33.3 \\
\hline Fritillaria & rhodocanakis & 134.9 & 3.1 & 24 & 1 & 172.3 & 37.4 \\
\hline Fritillaria & davisii & 138.9 & 2.3 & 24 & 4 & 179.0 & 40.1 \\
\hline Fritillaria & assyriaca** $^{* *}$ & 203.9 & 1.4 & 48 & 3 & 254.8 & 50.9 \\
\hline Fritillaria & assyriaca & 134.0 & 4.3 & 24 & 4 & & \\
\hline
\end{tabular}

${ }^{*}$ from literature. ${ }^{* *}=$ uva-vulpis, [15]. ${ }^{* * *}$ Bennett and Smith [16].

The chopping was done with a new razor blade in a Petri dish in $0.25 \mathrm{~mL}$ nuclei isolation buffer to which $0.25 \mathrm{mg}$ RNase/mL was added [8]. After adding $1.5 \mathrm{~mL}$ propidium iodide (PI) solution (50 mg PI/l in isolation buffer) the suspension with nuclei was filtered through a $30 \mu \mathrm{m}$ nylon filter. The fluorescence of the nuclei was measured half an hour and one hour after addition of PI, using a Partec CAII flow cytometer. The optical path contained an HBO mercury lamp, filters KG1, BG12, dichroic mirror TK500, filter OG570, and a Leitz $50 \times 1$ water immersion objective. Data were analyzed by means of DPAC software (Partec GmbH). If available, three different samples, and at least 3000 nuclei, were measured twice for each clone. Most histograms revealed a Coefficient of Variation (CV) of less than 5\%.

\subsection{Internal Standard and Absolute DNA Content Values.} When measuring nuclear DNA content by means of flow cytometry, it is necessary to chop tissue from the plant of interest together with an internal standard: this standard must be as close as possible to the plants of interest. In this way, variation in signal intensities due to staining kinetics, to light absorption and quenching by sample components, as well as to instrument and other variables, is reduced to a minimum. Haemanthus albiflos was chosen as internal standard, because it has a convenient amount of DNA relative to plants with very high DNA values. Moreover, it is available year-round, does not mind several weeks without water, and it can serve numerous determinations. It also has a low background in PI measurements and shows a single $\mathrm{G}_{0}$ peak, almost lacking $\mathrm{G}_{2}$ arrest. Fresh male human leucocytes $(2 \mathrm{C}=$ $7.0 \mathrm{pg}[12])\left(1\right.$ picogram $=0.978 \times 10^{9}$ base pairs [13] $)$ were chosen as primary standard. This yields $2 \mathrm{C}=15.9 \mathrm{pg}$ for nuclei of Agave americana. This in turn was used to measure Haemanthus albiflos and resulted in $2 \mathrm{C}=76.0 \mathrm{pg}$.

\section{Results}

3.1. The Monocots: Fritillaria, Trillium. The value of $2 \mathrm{C}=$ $254.8 \mathrm{pg}$ for Fritillaria assyriaca is usually presented as the highest genome size in articles using flow cytometrical methods (this volume!). In the list of plant DNA C-values [2], 19 out of 24 species of Fritillaria are by McLeish and LaCour. If these are compared with the present results (Table 1), they are all higher in 2C DNA value with an average increase of $32 \mathrm{pg}$. It runs from $11 \mathrm{pg}$ higher in F. verticillata (96.5 pg,) to $50 \mathrm{pg}$ higher in F. assyriaca (254.8 pg). If the present value of $2 \mathrm{C}=203.9 \mathrm{pg}$ for $F$. assyriaca hort. (= F. uva-vulpis) is used instead of $254.8 \mathrm{pg}$ of McLeish and LaCour, then several other species come in the same league like F. imperialis "Maxima" with $200.2 \mathrm{pg}$, and F. elwesii with $207.3 \mathrm{pg}$ (Table 1). For real high values one must look to Trillium (Melanthiaceae). Especially the trilliums of Asia have high C-values due to their usually high ploidy [14]. The new record holder presented here is T. hagae with $264.9 \mathrm{pg}$ $(2 n=30)$. It is an allohexaploid of $T$. camchatcense $(2 n=10)$ and T. tschonoskii $(2 n=20)$. Another high DNA $2 \mathrm{C}$-value is the Asiatic T. apetalon $(2 n=20)$ with $190.0 \mathrm{pg}$ [5].

3.2. The Eudicots:Viscum. Viscum cruciatum is with $2 \mathrm{C}$ $=158.7 \mathrm{pg}$ [17] presented in the list of plant DNA Cvalues [2] as the eudicot with the largest genome size. For $V$. album a value of $2 \mathrm{C}=152.0 \mathrm{pg}$ is chosen [18]. Clearly it is chosen as "prime estimate" as it is intermediate between the value of $\mathrm{Nagl}$ et al. for $V$. album with $2 \mathrm{C}=107.0 \mathrm{pg}$ [19] and those of Ulrich et al. with $2 \mathrm{C}=181.5 \mathrm{pg}$ [17]. It would have been better to choose both values from a single laboratory. Ulrich et al. [17] found the 2C-value of $V$. album to be higher than those of $V$. cruciatum and that is confirmed here. Ulrich et al. 
TABLE 2: Comparison of genome sizes (2C in pg) in this paper. \# = number of accessions.

\begin{tabular}{|c|c|c|c|c|c|c|c|c|}
\hline Species & & $2 \mathrm{C}$ in $\mathrm{pg}$ & S.D. & $2 n^{*}$ & \# & Nagl et al. [19] & Marie and Brown [18] & Ulrich et al. [17] \\
\hline Trillium & hagae & 264.9 & 3.2 & 30 & 1 & & & \\
\hline Trillium & apetalon & 190.0 & 4.1 & 20 & 2 & & & \\
\hline Viscum & album & 205.8 & 3.9 & 20 & 6 & 107.0 & ** 152.0 & 181.6 \\
\hline Viscum & cruciatum & 175.8 & 2.6 & 20 & 2 & & & $* * 158.7$ \\
\hline Viscum & crassulae & 164.0 & 3.6 & 24 & 1 & & & \\
\hline Viscum & minimum & 124.6 & 3.2 & 28 & 2 & & & \\
\hline Fritillaria & elwesii & 207.3 & 2.3 & 48 & 3 & & & \\
\hline Fritillaria & imp.Maxima & 200.2 & 0.3 & 48 & 2 & & & \\
\hline Fritillaria & assyriaca & 134.0 & 4.3 & 24 & 4 & & & \\
\hline Haemanthus & albiflos & 76.0 & 2.1 & 32 & 6 & & & \\
\hline Loranthus & europaeus [20] & 16.5 & & & & & & \\
\hline Orobanche & hederae [4] & 5.5 & 0.4 & 38 & 2 & & & \\
\hline Sedum & suaveolens & 18.3 & 2.4 & c640 & 4 & & & \\
\hline
\end{tabular}

*from literature. ** "Prime values" [2].

used several both A-T and G-C specific dyes and from these results calculated the "absolute DNA content." They also used Feulgen for $V$. album and obtained nearly the same result $(184.4 \mathrm{pg})$. The present results for these species are $2 \mathrm{C}=205.8 \mathrm{pg}$ for $\mathrm{V}$. album $(2 n=20)$, and $2 \mathrm{C}=175.8 \mathrm{pg}$ for $V$. cruciatum $(2 n=20)$ (Table 2). Also V. crassulae with $2 \mathrm{C}=164.0 \mathrm{pg}(2 n=24)$ and $V$. minimum with $2 \mathrm{C}=$ $124.6 \mathrm{pg}(2 n=28)$ are here presented as new DNA 2C-values (Table 2).

\section{Discussion}

Most of the values of Fritillaria in the list of plant DNA Cvalues are from McLeish and LaCour from 1971 [2]. They were measured with Feulgen cytometry and based on a personal communication. The standard species is unknown and they might not have used "best practice" as advocated for the Feulgen method [20]. The increasing difference of 11$50 \mathrm{pg}$ going from the lowest to the highest value in Fritillaria as presented by McLeish and LaCour compared with the present results (Table 1) suggest problems with the linearity of their measurements. Actually a 2C DNA value of $134 \mathrm{pg}$ was found for four accessions of the diploid F. assyriaca (Table 1). It cannot be excluded that McLeish and LaCour had a tetraploid F. assyriaca. However, it is more likely, they used the plant that is in the trade as F. assyriaca, but actually is the tetraploid F. uva-vulpis with $2 \mathrm{C}=203.9 \mathrm{pg}$. Moreover, Rix (1974) [15] has shown that up to that time all plants in commerce as F. assyriaca were a separate species F. uva-vulpis. The high values of McLeish and LaCour can be explained by the fact that they were obtained after recalibrating their values against $F$. pallidiflora with $116.7 \mathrm{pg}$ [16]. The present results show F. pallidiflora to have only $87.4 \mathrm{pg}$ (Table 1).

The combined results of the 2C DNA values of $0.129 \mathrm{pg}$ for Genlisea margaretae [11] with those presented here with $264.9 \mathrm{pg}$ for Trillium hagae increase the range of genome sizes for angiosperms to 2056-fold.

It may be wondered whether the high value found for $V$. album has anything to do with its parasitic nature. This seems not likely as the related tree parasite Loranthus europaeus has $16.5 \mathrm{pg}$ [18] and Orobanche hederae has $5.5 \mathrm{pg}$ [5]. The large genome size seems also not an impediment to growth rate. $V$. album on an apple tree in my garden reached football size and bear fruits in three years from seed.

\section{References}

[1] M. D. Bennett, I. J. Leitch, H. J. Price, and J. S. Johnston, "Comparisons with Caenorhabditis $(\sim 100 \mathrm{Mb})$ and Drosophila ( $\sim 175 \mathrm{Mb})$ using flow cytometry show genome size in Arabidopsis to be $\sim 157 \mathrm{Mb}$ and thus $\sim 25 \%$ larger than the Arabidopsis genome initiative estimate of $125 \mathrm{Mb}$," Annals of Botany, vol. 91, no. 5, pp. 547-557, 2003.

[2] M. D. Bennett and I. J. Leitch, "Angiosperm DNA Cvalues database (release 6.0, October 2005)," 2005, http://www.kew.org/cvalues/.

[3] T. R. Gregory, "A bird's-eye view of the C-value enigma: genome size, cell size, and metabolic rate in the class aves," Evolution, vol. 56, no. 1, pp. 121-130, 2002.

[4] B. J. M. Zonneveld and F. Van Iren, "Genome size and pollen viability as taxonomic criteria: application to the genus Hosta," Plant Biology, vol. 3, no. 2, pp. 176-185, 2001.

[5] B. J. M. Zonneveld, I. J. Leitch, and M. D. Bennett, "First nuclear DNA amounts in more than 300 angiosperms," Annals of Botany, vol. 96, no. 2, pp. 229-244, 2005.

[6] B. J. M. Zonneveld and G. D. Duncan, "Genome size for the species of Nerine Herb. (Amaryllidaceae) and its evident correlation with growth cycle, leaf width and other morphological characters," Plant Systematics and Evolution, vol. 257, no. 3-4, pp. 251-260, 2006.

[7] B. J. M. Zonneveld, "The systematic value of nuclear DNA content for all species of Narcissus L. (Amaryllidaceae)," Plant Systematics and Evolution, vol. 275, no. 1-2, pp. 109-132, 2008.

[8] B. J. M. Zonneveld, "The systematic value of nuclear genome size for all species of Tulipa L. (Liliaceae)," Plant Systematics and Evolution, vol. 281, no. 1-2, pp. 217-245, 2009.

[9] J. Greilhuber, "Evolutionary changes of DNA and heterochromatin amounts in the Scilla bifolia group (Liliaceae)," Plant Systematics and Evolution, supplement 2, pp. 263-280, 1979. 
[10] T. Cavalier-Smith, "Nuclear volume control by nucleoskeletal DNA, selection for cell volume and cell growth rate, and the solution of the DNA C-value paradox," Journal of Cell Science, vol. 34, pp. 247-278, 1978.

[11] J. Greilhuber, T. Borsch, K. Müller, A. Worberg, S. Porembski, and W. Barthlott, "Smallest angiosperm genomes found in Lentibulariaceae, with chromosomes of bacterial size," Plant Biology, vol. 8, no. 6, pp. 770-777, 2006.

[12] T. R. Tiersch, R. W. Chandler, S. S. Wachtel, and S. Elias, "Reference standards for flow cytometry and application in comparative studies of nuclear DNA content," Cytometry, vol. 10, no. 6, pp. 706-710, 1989.

[13] J. Doležel, J. Bartoš, H. Voglmayr, and J. Greilhuber, "Nuclear DNA content and genome size of trout and human," Cytometry Part A, vol. 51, no. 2, pp. 127-128, 2003.

[14] K. Samejima and J. Samejima, Trillium Genus Illustrated, Hokkaido University Press, Sapporo, Japan, 1987.

[15] E. M. Rix, "Notes on Fritillaria (Liliaceae) in the Eastern Mediterranean region I \& II," Kew Bulletin, vol. 29, no. 4, pp. 633-654, 1974.

[16] M. D. Bennett and J. B. Smith, "Nuclear DNA amounts in angiosperms," Philosophical transactions of the Royal Society of London. Series B, vol. 274, no. 933, pp. 227-274, 1976.

[17] I. Ulrich, B. Fritz, and W. Ulrich, "Application of DNA fluorochromes for flow cytometric DNA analysis of plant protoplasts," Plant Science, vol. 55, no. 2, pp. 151-158, 1988.

[18] D. Marie and S. C. Brown, "A cytometric exercise in plant DNA histograms, with 2C-values for 70 species," Biology of the Cell, vol. 78, no. 1-2, pp. 41-51, 1993.

[19] W. Nagl, M. Jeanjour, H. Kling, et al., "Genome and chromatin organization in higher plants," Biologisches Zentralblatt, vol. 102, pp. 129-148, 1983.

[20] J. Greilhuber and E. M. Temsch, "Feulgen densitometry: some observations relevant to best practice in quantitative nuclear DNA content determination," Acta Botanica Croatica, vol. 60, no. 2, pp. 285-298, 2001. 

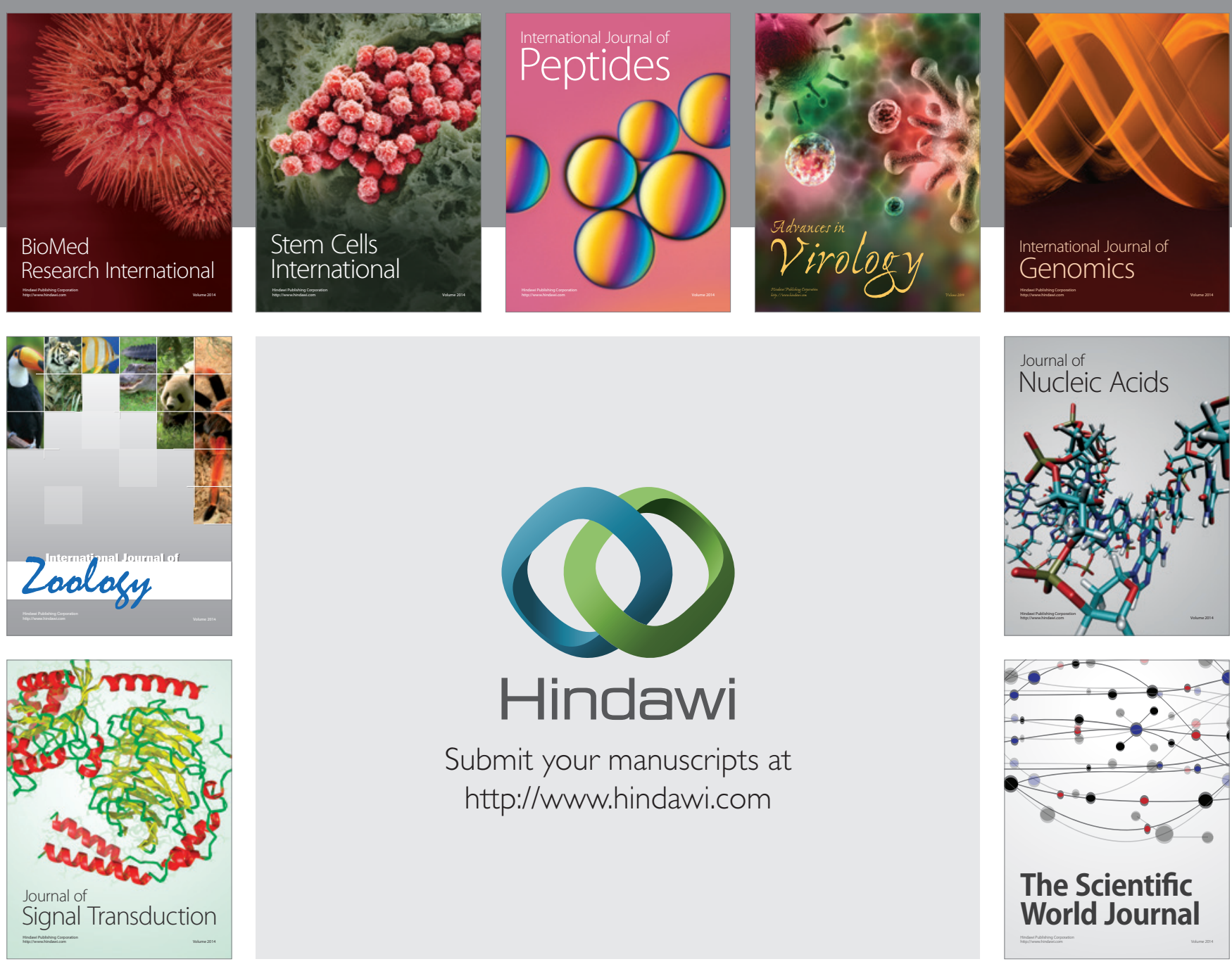

Submit your manuscripts at

http://www.hindawi.com
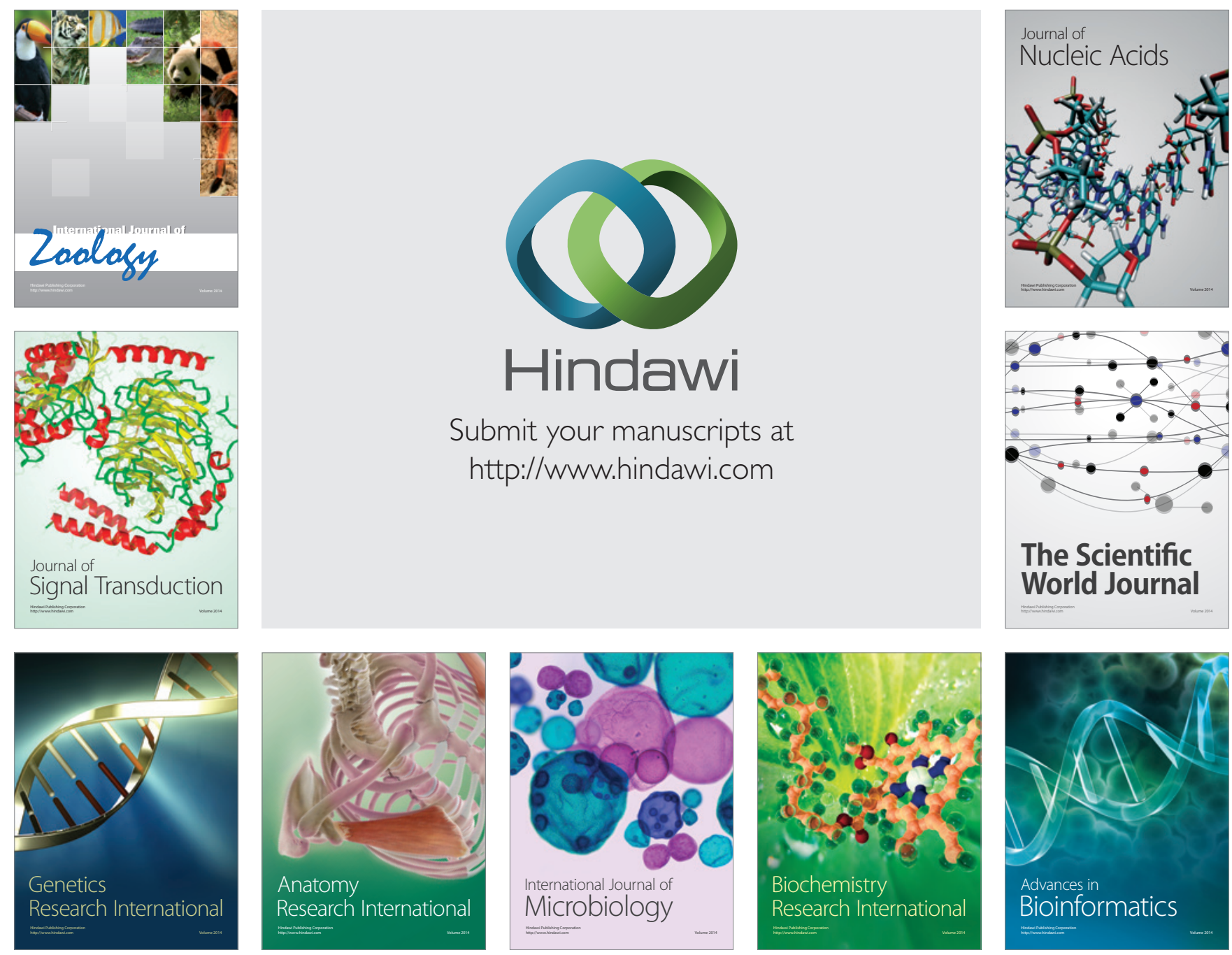

The Scientific World Journal
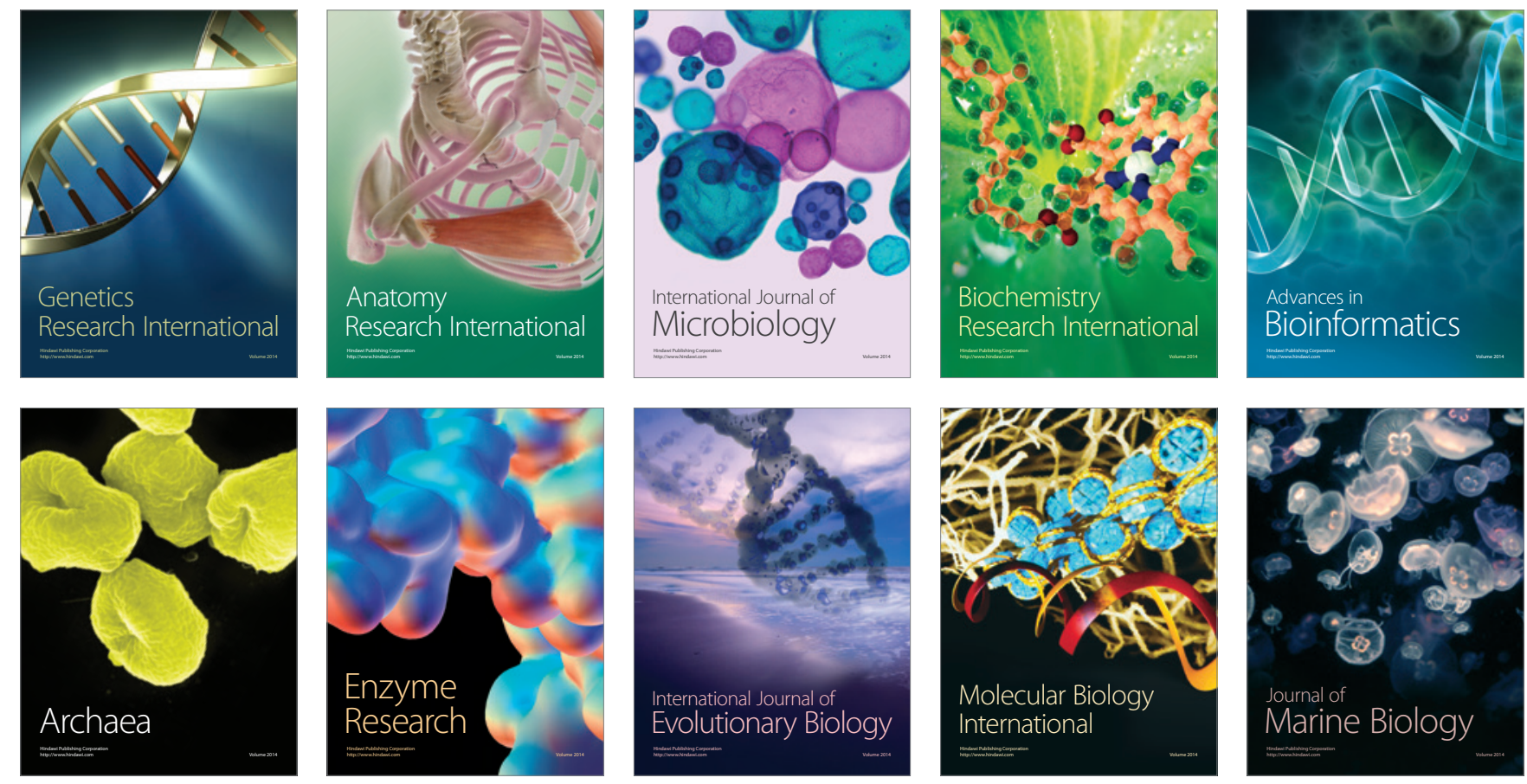